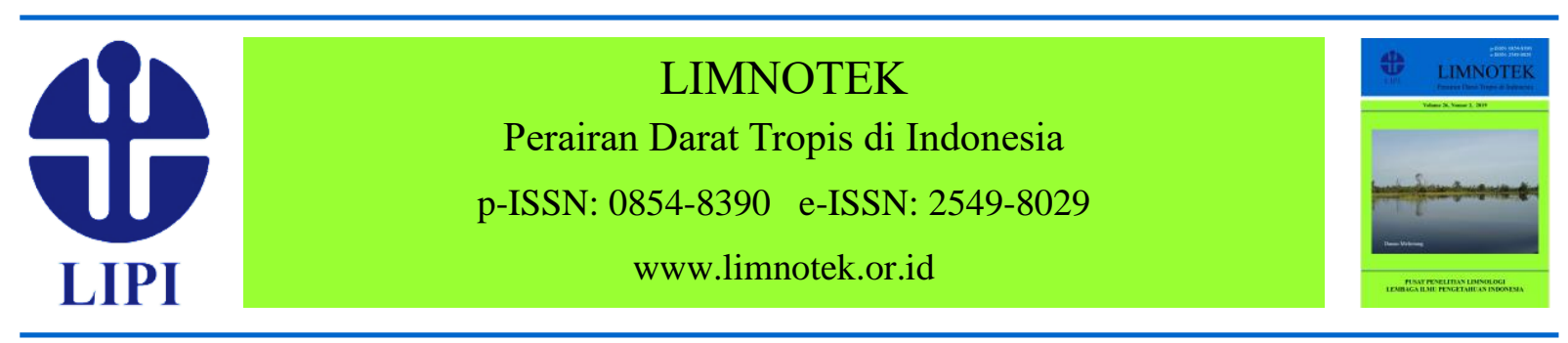

\title{
Kesesuaian Lahan Berdasarkan Indeks Konservasi Secara Spasial di DAS Ciasem Hulu, Subang
}

\author{
Hilda Lestiana, Asep Mulyono, Rizka Maria, Dedi Mulyadi \\ Pusat Penelitian Geoteknologi, Lembaga Ilmu Pengetahuan Indonesia \\ Email: hilda.lestiana@gmail.com
}

Diajukan 21 November 2017. Ditelaah 22 Oktober 2018. Disetujui 13 Agustus 2019.

\begin{abstract}
Abstrak
Degradasi lahan akibat perubahan penggunaan lahan dari area hutan dan pertanian menjadi kawasan terbangun di wilayah Daerah Aliran Sungai (DAS) Ciasem hulu terus berlangsung dan perlu mendapat perhatian dikarenakan wilayah ini termasuk ke dalam kawasan resapan air. Kajian kesesuaian lahan berdasarkan penghitungan indeks konservasi dilakukan untuk menunjukkan kemampuan suatu wilayah dalam menyerap air hujan yang jatuh ke permukaan tanah dan menjadi imbuhan air tanah. Indeks konservasi dihitung berdasarkan kondisi aktual dan kondisi alaminya. Melalui pendekatan analisis spasial, distribusi kesesuaian lahan di DAS Ciasem hulu telah dievaluasi. Dengan pendekatan spasial, daerahdaerah yang perlu mendapat perhatian dapat diketahui secara langsung. Kecamatan Jalancagak dan Sagalaherang perlu mendapat perhatian lebih dibandingkan tiga kecamatan lain di DAS Ciasem hulu. Degradasi terjadi cukup tinggi, terutama sejak tahun 2009 dan lebih tinggi lagi pada tahun 2014. Skenario penataan penggunaan lahan tahun 2030 masih perlu dikaji lebih lanjut agar mampu meningkatkan kualitas peresapan yang telah terdegradasi sejak tahun 2009. Hasil analisis menunjukkan bahwa penilaian kesesuaian lahan yang hanya didasarkan pada perubahan kelas indeks konservasi aktual terhadap kelas indeks konservasi alami belum dapat menggambarkan kesesuaian lahan yang sebenarnya. Penilaian ini memiliki kelemahan jika tingkat kesesuaian lahan hanya memperhatikan perubahan kelas indeks konservasi aktual terhadap kelas indeks konservasi alami. Nilai kondisi alami merupakan hal yang penting dalam penilaian kesesuaian lahan. Kelas kesesuaian lahan di DAS Ciasem hulu terdiri dari tiga kategori, yaitu sesuai, kritis, dan sangat kritis. Penghitungan berdasarkan indeks konservasi menunjukkan banyak daerah yang memiliki kondisi alami kurang baik. Daerah dengan kategori sesuai menurut penghitungan mempunyai kondisi aktual kurang baik dan daerah dengan kategori sangat kritis mempunyai kondisi aktual lebih buruk.
\end{abstract}

Kata kunci: kesesuaian lahan, indeks konservasi, penggunaan lahan, DAS Ciasem hulu

\begin{abstract}
Land Suitability Based on the Spatial Conservation Index in the Upstream of Ciasem Watershed in Subang District. Land degradation due to changes in land use from forest land and agricultural land into the built-up areas in the upstream of the Ciasem watershed area continues and needs attention because this area belongs to the water recharge area. A land suitability study based on the
\end{abstract}


conservation index calculation was conducted to show the ability of an area to absorb rainwater that falls to the ground and becomes groundwater recharge. The conservation index was calculated based on actual and natural conditions. Through a spatial approach, the distribution of land suitability in the upstream of Ciasem watershed was analyzed. Using the spatial approach, the areas that needed attention could be identified directly. Jalancagak and Sagalaherang sub-districts needed more attention than the other three sub-districts in the upstream of Ciasem watershed. Degradation has been quite high, especially since 2009, and even higher since 2014. The land-use scenario in 2030 still needs to be studied further to improve the quality of infiltration that has been degraded since 2009. The results of the analysis showed that the land suitability assessment, which was based on the changes in the actual to the natural conservation index class have not been able to describe the actual suitability of the land. This assessment has a weakness if the land suitability level only considers changes in the actual as opposed to the natural conservation index class. The value of natural conditions is important in assessing land suitability. The land suitability class in the upstream of Ciasem watershed consists of three categories: appropriate, critical, and very critical. Calculations based on the conservation index show that many areas have poor natural conditions. Regions with the appropriate category, according to the calculations, show that the actual conditions are worse, and regions in the 'very critical' categories have the worst actual conditions.

Keywords: land suitability, conservation index, land use, upstream of the Ciasem watershed

\section{Pendahuluan}

Daerah Aliran Sungai (DAS) Ciasem merupakan salah satu DAS yang berada di satuan Wilayah Sungai (WS) Citarum dengan hulu sungai berada di Gunung Tangkuban Parahu dan bermuara di Teluk Ciasem dengan panjang sungai $184,9 \mathrm{~km}$ dan luas $734,1 \mathrm{~km}^{2}$ (Dinas Sumberdaya Air, 2017). Kawasan DAS Ciasem terdiri atas tiga zona, yaitu hulu, tengah, dan hilir yang mencakup 12 kecamatan dalam wilayah administratif Kabupaten Subang. Penelitian dilaksanakan di wilayah hulu DAS Ciasem yang meliputi Kecamatan Sagalaherang, Jalancagak, dan Cijambe yang termasuk dalam Wilayah Pengembangan (WP) Jalancagak, Kabupaten Subang. Secara hierarki, wilayah pengembangan ini merupakan pusat kegiatan pariwisata, pusat pelayanan kesehatan, pusat jasa perekonomian, pusat pendidikan menengah dan tinggi, dan pusat permukiman perkotaan (Bappeda Kabupaten Subang, 2009).

Kodoatie (2010) menyatakan pemanfaatan ruang mengacu pada fungsi ruang yang ditetapkan dalam rencana tata ruang dan dilaksanakan dengan mengembangkan penatagunaan tanah, air, udara, dan sumber daya alam lain. Masalah penurunan kualitas lahan dan lingkungan di wilayah pengembangan beriring dengan peningkatan perubahan tata guna lahan menjadi permukiman dan industri yang tidak sesuai dengan tata ruang wilayah. Fenomena alih fungsi lahan hutan dan pertanian menjadi kawasan permukiman, industri, dan wisata (kawasan terbangun) di wilayah tersebut berlangsung relatif cepat. Secara administratif, hal ini dapat mengganggu fungsi beberapa wilayah kecamatan yang mempunyai kawasan-kawasan penting untuk tujuan konservasi, seperti kawasan resapan air, kawasan lindung, kawasan cagar alam, kawasan suaka margasatwa, kawasan taman wisata alam, kawasan lindung sempadan sungai, dan kawasan sumber mata air. Perubahan lahan suatu kawasan akan memengaruhi fungsi hidrogeologis dan dinamika perubahannya secara ruang dan waktu (Maria \& Lestiana, 2014). Proses peresapan air hujan mulai dari permukaan tanah sampai ke sistem air tanah dalam merupakan bagian siklus hidrologi. Dalam konservasi sumber daya air, air hujan yang mengalir masuk sebagai pasokan air tanah akan menstabilkan aliran air sungai (Fakhrudin \& Daruati, 2017).

Indeks konservasi adalah suatu nilai yang menunjukkan kemampuan suatu wilayah untuk menyerapkan air hujan yang jatuh di atasnya ke dalam lapisan tanah, sehingga menjadi sumber imbuhan air tanah. Indeks konservasi digunakan untuk menilai kesesuaian suatu lahan. Indeks tersebut dihitung berdasarkan parameter kemiringan lahan, jenis batuan, jenis tanah, curah hujan, dan penggunaan lahan. Beberapa hasil penelitian menunjukkan bahwa analisis kesesuaian telah diterapkan dalam penilaian lahan pertanian (Feizizadeh \& Blaschke, 2013), evaluasi lanskap dan perencanaan wilayah dan kajian dampak lingkungan (Rojas et al., 2013; Marull et al., 2007). 
Menurut Sabar (1999), evaluasi kemampuan lahan telah umum dilakukan dan menjadi salah satu komponen utama yang dipertimbangkan dalam penyusunan rencana pemanfaatan lahan. Evaluasi kemampuan lahan pada dasarnya merupakan evaluasi potensi lahan untuk digunakan dalam bidang pertanian secara luas, dengan tidak memasukkan peruntukannya untuk jenis tanaman tertentu maupun tindakan-tindakan pengelolaan yang mungkin diperlukan. Oleh sebab itu, sifatnya merupakan evaluasi yang lebih umum dibandingkan dengan evaluasi kesesuaian lahan yang bersifat lebih khusus. Kecenderungan nilai fungsi sumber daya lahan akan terus berlangsung seiring dengan perubahan penggunaan lahan. Analisis kesesuaian lahan sangat penting dilakukan, terutama dalam mengidentifikasi pola ruang untuk kebutuhan penggunaan pada masa mendatang (Collins et al., 2001). Dalam penelitian ini indeks konservasi akan digunakan untuk menilai tingkat kesesuaian lahan di DAS Ciasem hulu dengan menggunakan dasar informasi spasial Rencana Tata Ruang dan Wilayah (RTRW) tahun 2030 yang kemudian dibandingkan dengan kondisi historis tahun 2009 dan 2014.

\section{Bahan dan Metode}

Kesesuaian lahan berdasarkan indeks konservasi dianalisis dengan melakukan pembobotan pada parameter tertentu dan proses klasifikasi secara spasial. Analisis kesesuaian lahan mengacu pada penilaian indeks konservasi alami $\left(\mathrm{IK}_{\mathrm{A}}\right)$ dan indeks konservasi aktual $\left(\mathrm{IK}_{\mathrm{C}}\right)$ (Sabar, 1999). Penghitungan indeks konservasi alami $\left(\mathrm{IK}_{\mathrm{A}}\right)$ dilakukan dengan cara menggabungkan peta parameter kemiringan lahan, batuan permukaan, dan curah hujan dengan metode tumpang tindih. Tumpang tindih peta ketiga parameter tersebut menghasilkan peta satuan unit lahan. Setiap unit lahan akan mempunyai kemampuan meresapkan air yang berbeda (Rismana \& Firmansyah, 2011). Selain itu, indeks konservasi aktual $\left(\mathrm{IK}_{\mathrm{C}}\right)$ merupakan indeks konservasi alami ditambahkan parameter penggunaan lahan (Gambar 1).

Masing-masing parameter faktor indeks konservasi diberikan bobot tingkat peresapan yang ditunjukkan dalam Tabel 1 . Nilai $\mathbf{I K}_{\mathrm{A}}$ maupun $\mathrm{IK}_{\mathrm{C}}$ diklasifikasikan menjadi lima kelas secara kualitatif, yaitu sangat rendah $(0,0-0,2)$, rendah $(0,2-0,4)$, sedang $(0,4-0,6)$, tinggi $(0,6-$ $0,8)$, dan sangat tinggi $(0,8-1,0)$. Penilaian klasifikasi kesesuaian lahan dilakukan dengan cara menganalisis perbandingan nilai kondisi aktual $\left(\mathrm{IK}_{\mathrm{C}}\right)$ terhadap kondisi alaminya $\left(\mathrm{IK}_{\mathrm{A}}\right)$ dengan kriteria pada Tabel 2.

Peta kemiringan lahan diperoleh dari hasil ekstraksi data topografi skala 1:25.000. Pengkelasan terbagi menjadi 5 satuan kemiringan lahan, yaitu lereng datar 0-8\% (22.974 ha), lereng 8-15\% (11.630 ha), lereng 15-20\% (3.998 ha), lereng $20-40 \%$ (4.488 ha), dan lereng lebih dari $40 \%$ (10.961 ha).

Tabel 1. Bobot masing-masing parameter indeks konservasi (modifikasi dari Sabar, 1999)

\begin{tabular}{|c|c|c|c|c|c|}
\hline Lereng (\%) & Batuan permukaan & Curah hujan (mm) & Penggunaan lahan & Bobot & Kategori \\
\hline $0-8$ & $\begin{array}{l}\text { Endapan vulkanik } \\
\text { muda }\end{array}$ & $4500-5000$ & Hutan, air tawar & 0,95 & Sangat tinggi \\
\hline $8-15$ & Batu pasir, lava & $4000-4500$ & Tegalan, kebun & 0,8 & Tinggi \\
\hline $15-20$ & $\begin{array}{l}\text { Alluvium endapan } \\
\text { dataran }\end{array}$ & $3500-4000$ & $\begin{array}{l}\text { Semak, padang } \\
\text { rumput }\end{array}$ & 0,6 & Sedang \\
\hline $20-30$ & $\begin{array}{l}\text { Koluvium, endapan } \\
\text { vulkanik tua }\end{array}$ & $3000-3500$ & Sawah & 0,4 & Rendah \\
\hline $30-40$ & Lempung & $2500-3000$ & Permukiman & 0,2 & Sangat rendah \\
\hline
\end{tabular}




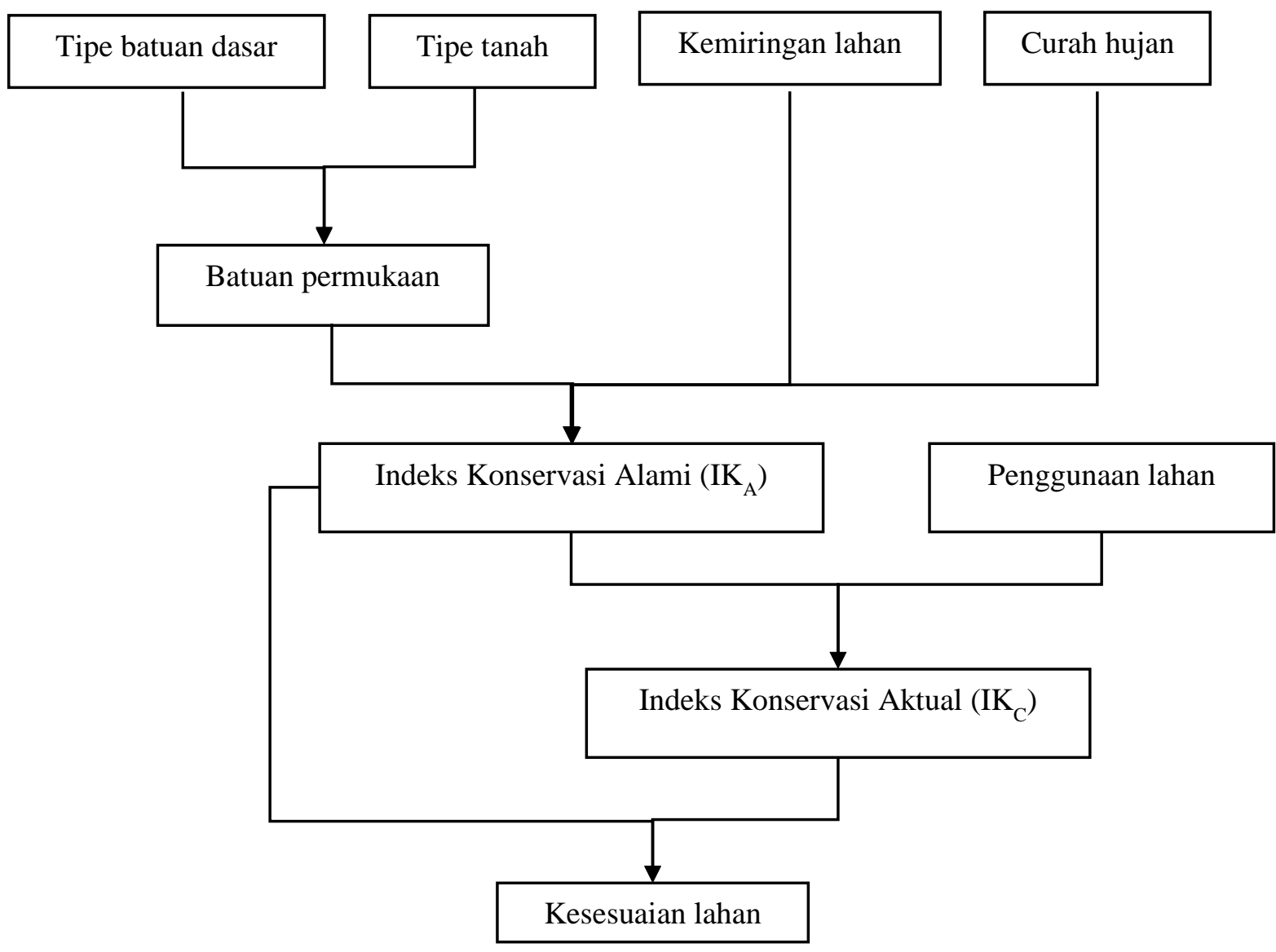

Gambar 1. Bagan alir penghitungan kesesuaian lahan

Tabel 2. Kriteria klasifikasi kesesuaian lahan (Rismana \& Firmansyah, 2011)

\begin{tabular}{|c|c|}
\hline Klasifikasi & Parameter \\
\hline Sangat baik & Bila $I_{\mathrm{C}}>$ dua kelas atau lebih dari $\mathrm{IK}_{\mathrm{A}}$ \\
\hline Baik & Bila $I K_{C}>$ satu kelas dari $I_{K_{A}}$ \\
\hline Sesuai (Sedang) & Bila $\mathrm{IK}_{\mathrm{C}}=\mathrm{IK}_{\mathrm{A}}$ \\
\hline Kritis & Bila $\mathrm{IK}_{\mathrm{C}}<$ satu kelas dari $\mathrm{IK}_{\mathrm{A}}$ \\
\hline Sangat kritis & Bila $\mathrm{IK}_{\mathrm{C}}<$ dua kelas atau lebih dari $\mathrm{IK}_{\mathrm{A}}$ \\
\hline
\end{tabular}

Pembagian kelas batuan permukaan mengacu pada jenis batuan dasar dan dikaitkan dengan sifat fisik jenis tanah. Jenis batuan dasar diperoleh dari kondisi geologi yang menggambarkan jenis batuan permukaan. Jenis batuan dasar ini mengacu pada peta geologi skala 1:100.000 (Silitonga, 1973). Geologi daerah Subang pada umumnya terdiri atas produk gunung api hasil erupsi Gunung Tangkuban Parahu dan Gunung Api Sunda. Tingkat kelulusan batuan di wilayah penelitian dominan ditempati oleh batuan vulkanik dan koluvium dengan kategori peresapan sangat rendah-sedang yang menempati $64 \%$ dari keseluruhan wilayah. Berdasarkan Soil Survey
Staff (2010) tanah di wilayah studi terdiri dari empat jenis, yaitu Inceptisols, Andisols, Ultisols, dan Entisols (Mulyono et al., 2011). Hasil pengamatan kedalaman tanah efektif di lapangan untuk masing-masing jenis tanah berkisar 30-60 $\mathrm{cm}, 60-90 \mathrm{~cm}$, dan lebih dari $90 \mathrm{~cm}$ terutama di wilayah lereng datar-agak datar.

Data jumlah curah hujan tahunan yang dipakai sebagai penghitungan indeks konservasi alami menyesuaikan tahun penggunaan lahan, yaitu tahun 2009 dan 2014. Meskipun curah hujan masuk dalam penghitungan kondisi alami, akan tetapi nilainya tidak konstan dalam jangka waktu yang lama. Pemakaian tahun yang berbeda untuk 
indeks konservasi aktual, dikarenakan curah hujan memiliki nilai yang bervariasi. Jumlah curah hujan tahunan pada tahun 2009 berbeda dari tahun 2014. Jumlah curah hujan di daerah penelitian secara umum mengalami kecenderungan meningkat. Stasiun pengamatan yang dipakai adalah stasiun pengamatan milik PSDA Provinsi Jawa Barat, yaitu Stasiun Cisampih, Ciherang, Cisalak, dan Cipeusing. Jumlah curah hujan tahunan tertinggi tercatat pada tahun 2009 di Stasiun Cisampih, yaitu $3.565 \mathrm{~mm}$ dan pada tahun 2014 di Stasiun Ciherang setinggi $3.388 \mathrm{~mm}$. Selain itu, jumlah curah hujan terendah terjadi di Stasiun Cipeusing, yaitu $1.114 \mathrm{~mm}$ pada tahun 2009 dan $2.034 \mathrm{~mm}$ pada tahun 2014.

Penggunaan lahan tahun 2014 mengalami pengurangan luas hutan jika dibandingkan dengan kondisi luas jenis lahan yang sama pada tahun 2009. Meskipun demikian, peta rencana tutupan lahan tahun 2030 mempunyai luas hutan yang meningkat, didesain untuk melebihi luas hutan pada tahun 2009 dengan status menjadi hutan lindung. Semak belukar di beberapa wilayah dikonversi menjadi hutan produksi, hutan lindung, permukiman, perkebunan, dan pertanian lahan basah (Tabel 3).

\section{Hasil}

Indeks konservasi alami $\left(\mathrm{IK}_{\mathrm{A}}\right)$ dihitung berdasarkan nilai parameter kemiringan lahan, batuan permukaan, dan curah hujan. Indeks konservasi aktual $\left(\mathrm{IK}_{\mathrm{C}}\right)$ dihitung berdasarkan kelas $\mathrm{IK}_{\mathrm{A}}$ ditambah kelas penggunaan lahan. Proses penghitungan dan analisis dilakukan untuk setiap periode data, yaitu tahun 2009, 2014, dan 2030, sehingga diperoleh perbandingan luas berdasarkan kriteria indeks di setiap kecamatan. Secara umum, baik nilai indeks konservasi alami maupun indeks konservasi aktual di DAS Ciasem hulu memiliki nilai yang kurang baik. Persentase luas kategori indeks konservasi sangat tinggi dapat dikatakan hampir tidak ada. Semakin turun nilai kualitas indeks konservasinya, persentase luasnya semakin bertambah (Gambar 2).

Kesesuaian lahan dinilai berdasarkan kondisi aktual dibandingkan dengan kondisi alaminya. Hasil penghitungan menunjukkan DAS Ciasem hulu memiliki kondisi kesesuaian lahan sesuai, kritis, dan sangat kritis, seperti terlihat dalam Gambar 3 (tahun 2009), Gambar 4 (tahun 2014), dan Gambar 5 (tahun 2030).

Tabel 3. Luas penggunaan lahan tahun 2009, 2014, dan rencana tahun 2030

\begin{tabular}{lrlrlr}
\hline \multicolumn{1}{c}{ Tahun 2009 } & Luas (ha) & Tahun 2014 & Luas (ha) & \multicolumn{1}{c}{ Tahun 2030 } & \multicolumn{1}{c}{ Luas (ha) } \\
\hline Hutan & 8.068 & Hutan & 1.761 & Hutan lindung & 8.800 \\
Kebun & 15.172 & Hutan industri & 13.276 & Hutan produksi & 6.358 \\
Ladang & 8.222 & Ladang & 4.311 & Kebun campuran & 18.657 \\
Padang rumput & 256 & Permukiman & 1.667 & Kebun rapat & 4.939 \\
Permukiman & 2.993 & Perkebunan & 5.555 & Permukiman & 2.612 \\
Sawah & 10.924 & Sawah & 11.589 & Pertanian lahan basah & 12.686 \\
Semak belukar & 8.286 & Semak belukar & 15.864 & & \\
Tanah terbuka & 18 & Tanah terbuka & 27 & & \\
Air tawar & 115 & Badan air & 2 & & \\
\hline Luas & 54.053 & & 54.053 & & \\
\hline
\end{tabular}




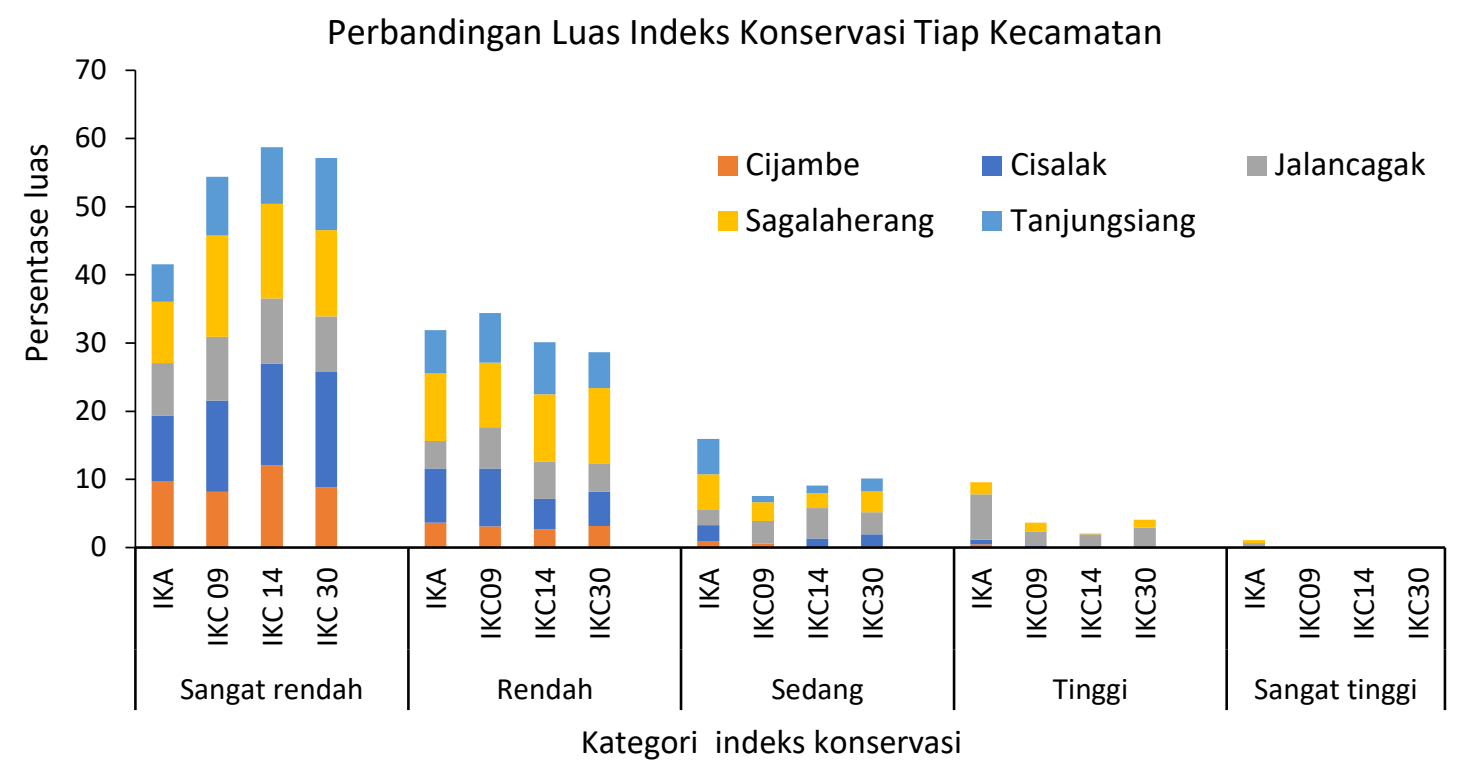

Gambar 2. Perbandingan persentase luas Indeks Konservasi Alami $\left(\mathrm{IK}_{\mathrm{A}}\right)$ dengan Indeks Konservasi Aktual $\left(\mathrm{IK}_{\mathrm{C}}\right)$ tahun 2009, 2014, dan 2030 setiap kecamatan

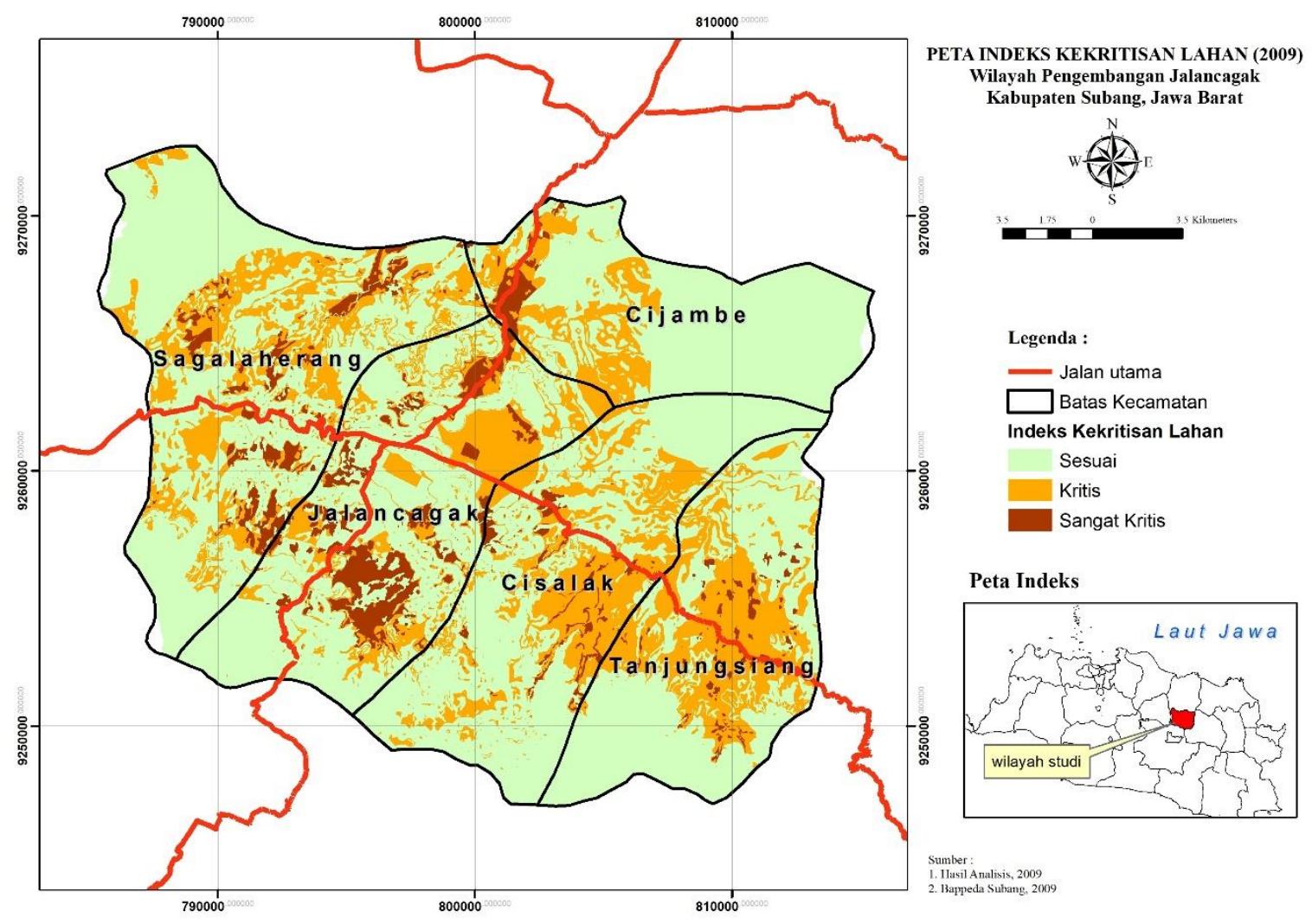

Gambar 3. Tingkat kesesuaian lahan tahun 2009 


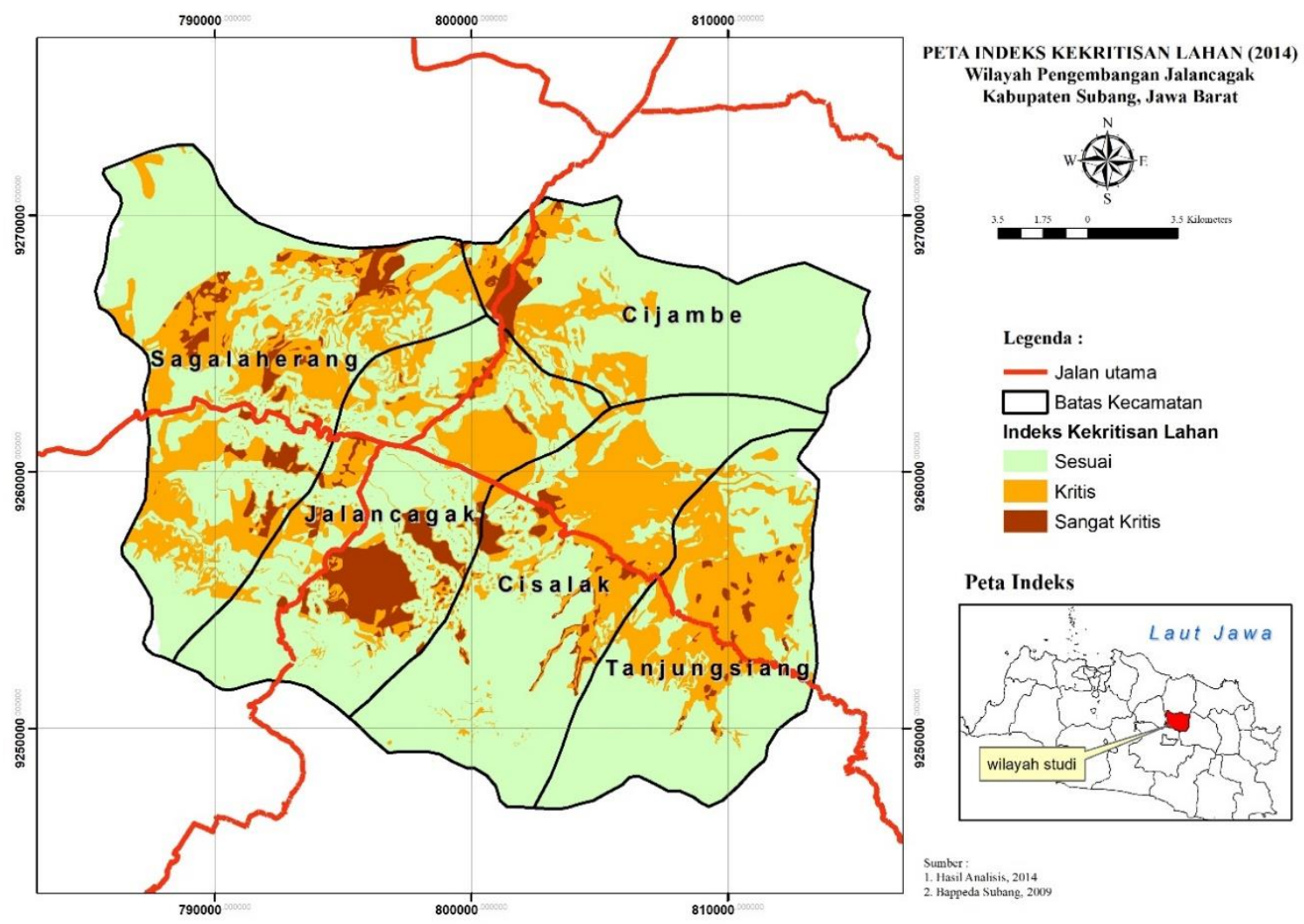

Gambar 4. Tingkat kesesuaian lahan tahun 2014

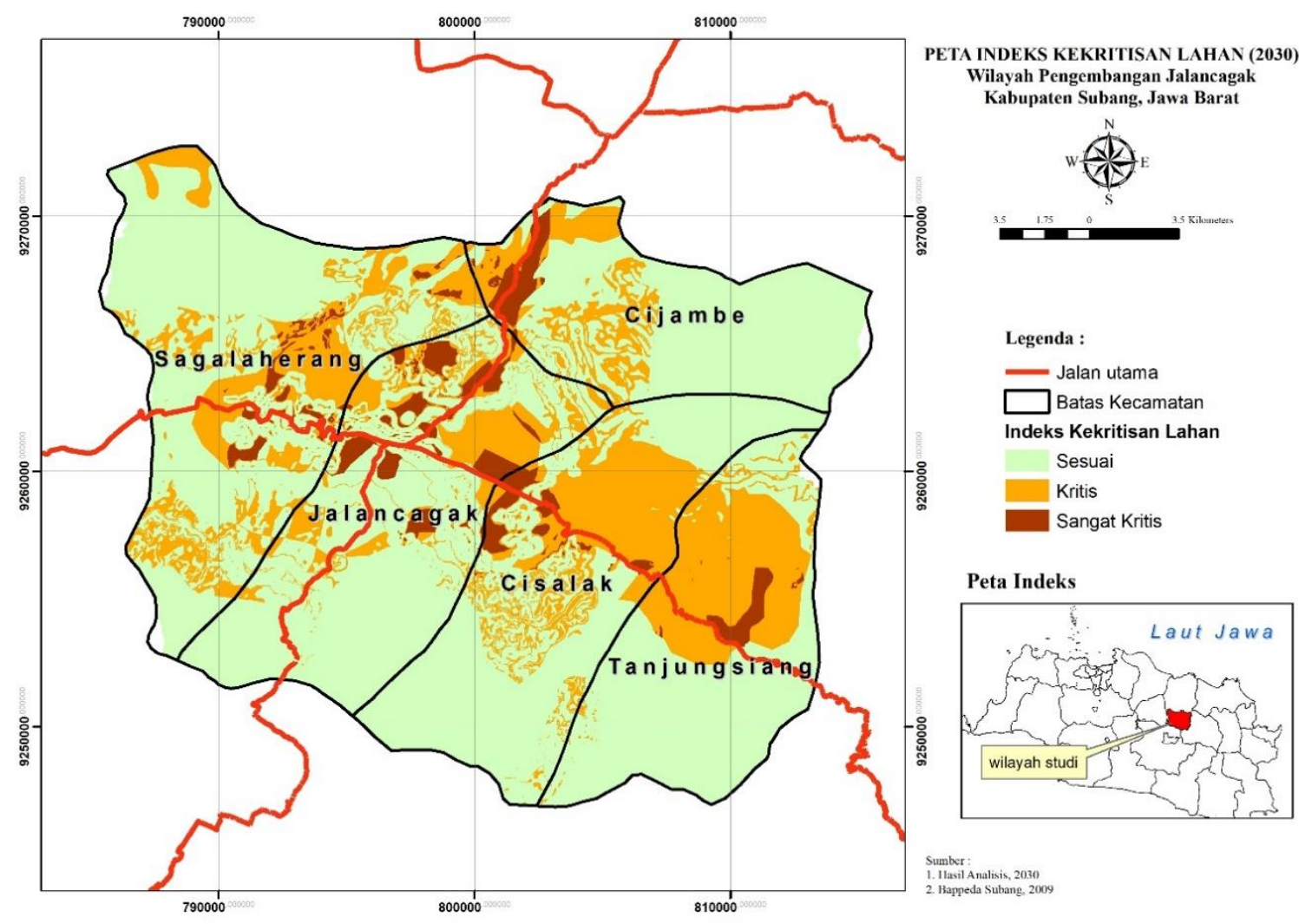

Gambar 5. Tingkat kesesuaian lahan tahun 2030 
Hasil penelitian ini menunjukkan bahwa pada tahun 2009 lahan dengan kategori sesuai mempunyai luas $67 \%$ atau 36.067 ha (Gambar 3) dari total area DAS, kemudian menurun menjadi 65\% atau 34.926 ha pada tahun 2014 (Gambar 4), dan pada tahun 2030 (Gambar 5) diperkirakan meningkat kembali menjadi $69 \%$ atau 37.422 ha. Lahan dengan kategori kritis pada tahun 2009 mempunyai luas 14.629 ha, meningkat sebesar 1.299 ha pada tahun 2014 menjadi 15.928 ha, dan menurun 389 ha dari tahun 2009 menjadi 14.240 ha pada tahun 2030, sedangkan luas lahan dengan kategori sangat kritis pada tahun 2030 menjadi lebih kecil dibanding tahun 2009 dan 2014, menjadi 2.391 ha. Lahan yang dikategorikan kritis sampai dengan sangat kritis tersebar di seluruh kecamatan di DAS Ciasem hulu. Persentase total luas wilayah dengan kategori kritis dan sangat kritis sebesar $33 \%$ pada tahun 2009, 35\% pada tahun 2014, dan pada skenario tahun 2030 berubah menjadi sebesar $31 \%$ dari luas total lahannya.

\section{Pembahasan}

Lahan kritis merupakan lahan yang telah mengalami kerusakan dan kehilangan fungsi hidrologis dan fungsi ekonomisnya. Dengan kata lain, lahan tersebut tidak lagi mampu mengatur persediaan air serta tidak mampu berproduksi. Pada umumnya, daerah-daerah tersebut mengalami kerusakan akibat penggunaan lahan tanpa memperhatikan usaha konservasi dan kelestarian tanah dan air. Ciri lahan kritis secara sederhana adalah lahan yang sudah tidak berfungsi lagi sebagai media pengatur tata air dan unsur lingkungan lahan secara baik.

Analisis spasial telah dilakukan untuk melihat kesesuaian lahan wilayah DAS Ciasem hulu. Analisis perbandingan penggunaan lahan aktual dengan rencana pemanfaatan ruang dari peta RTRW dilakukan untuk mengetahui kesesuaian dan kekonsistenan pemanfaatan ruang saat ini dengan alokasi rencana tata ruang yang telah disusun. Peta RTRW dibuat sebagai pedoman pelaksanaan pemanfaatan ruang untuk masa depan (Nuraeni \& Sitorus, 2017). Penggunaan data spasial yang bersifat temporal sangat bermanfaat untuk analisis perubahan penggunaan lahan suatu wilayah, khususnya untuk mengetahui lokasi-lokasi tempat perubahan penggunaan lahan terjadi (As-Syakur et al., 2010).

Gambar 6 menunjukkan kondisi perubahan kekritisan lahan tahun 2009-2014. Pada periode tersebut, terjadi peningkatan dan penurunan kategori kekritisan lahan. Namun, yang signifikan terjadi peningkatan wilayah dengan kategori kritis dan sangat kritis, masing-masing sebesar 1.299 ha dan 158 ha di semua wilayah. Wilayah dengan peningkatan luas lahan dengan kategori kritis terluas terjadi di Kecamatan Sagalaherang (1.105 ha), dan sisanya terjadi di Kecamatan Jalancagak sebesar 442 ha. Untuk kategori lahan sangat kritis terjadi peningkatan di Kecamatan Cijambe (55 ha), dan Kecamatan Cisalak (42 ha). Pada periode tersebut terjadi penurunan wilayah dengan kategori sesuai dengan area total 1.141 ha. Penurunan terluas terjadi di Kecamatan Sagalaherang (1.093 ha) dan Kecamatan Jalancagak (247 ha).

Gambar 7 menunjukkan kondisi perubahan kekritisan lahan periode 2014-2030. Terlihat bahwa terjadi peningkatan wilayah dengan kategori sesuai sebagai akibat dari rencana penggunaan lahan pada tahun 2030. Peningkatan luas lahan dengan kategori sesuai terjadi di Kecamatan Sagalaherang (1.554 ha), Kecamatan Jalancagak (1.205 ha), dan Kecamatan Tanjungsiang (50 ha). Namun, terjadi penurunan luas lahan dengan kategori sesuai di Kecamatan Cijambe (162 ha) dan Kecamatan Cisalak (151 ha). Pada kategori kritis, tahun 2014-2030 terjadi penurunan di Kecamatan Jalancagak (800 ha), Kecamatan Sagalaherang (1.058 ha), dan Kecamatan Tanjungsiang (114 ha). Peningkatan luas lahan dengan kategori kritis terjadi di Kecamatan Cijambe (135 ha) dan Kecamatan Cisalak (149 ha). Untuk lahan dengan kategori sangat kritis, pada periode 2014-2030 terjadi peningkatan terluas di Kecamatan Cijambe (71 ha), sedangkan penurunan terluas terjadi di Kecamatan Sagalaherang (485 ha). Pada periode 2014-2030, penurunan total luas lahan dengan kategori kritis adalah 1.688 ha, sedangkan kategori sangat kritis seluas 808 ha di seluruh wilayah penelitian. Lahan-lahan dengan kategori kritis dan sangat kritis secara harfiah telah dan sedang mengalami degradasi. Perbaikan tanah yang telah terdegradasi relatif sulit, sehingga tanah-tanah tetap gundul dan hancur (Hardjowigeno, 1995). 
Perubahan Indeks Kesesuaian Lahan 2009 ke 2014

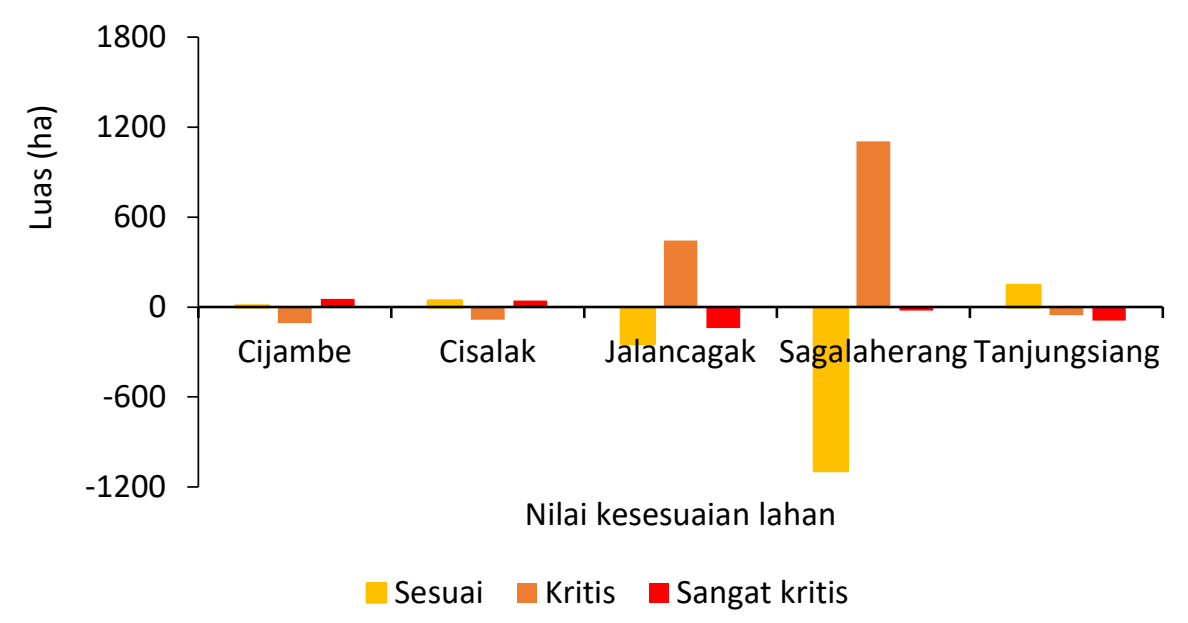

Gambar 6. Grafik perubahan kesesuaian lahan per kecamatan tahun 2009-2014

Perubahan Indeks Kesesuaian Lahan 2014 ke 2030

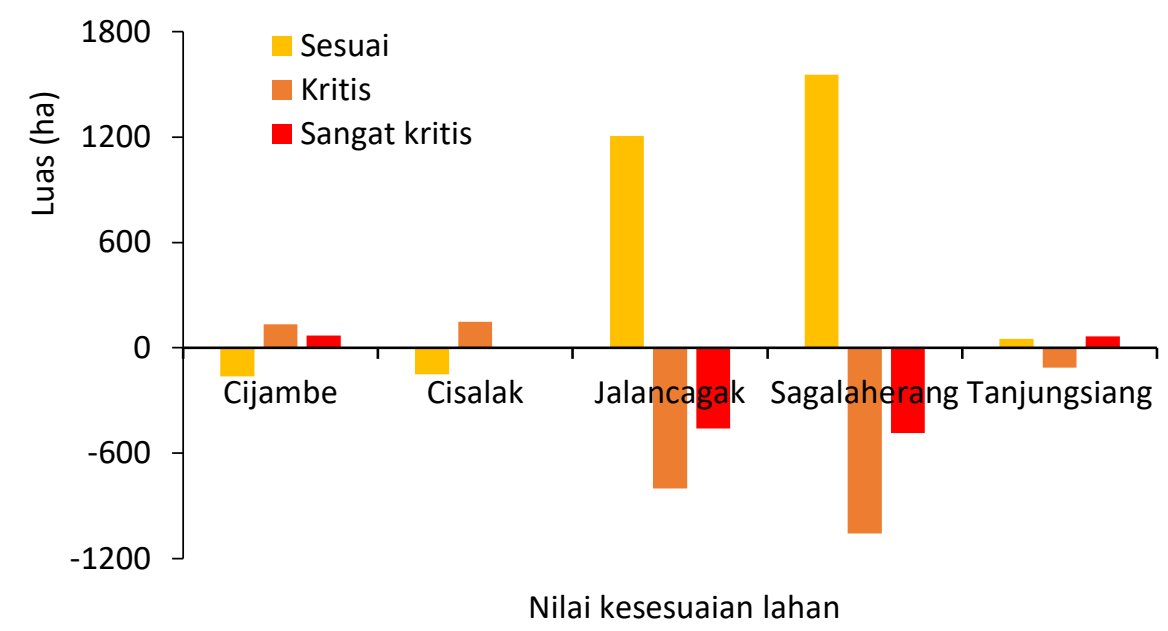

Gambar 7. Grafik perubahan kesesuaian lahan per kecamatan tahun 2014-2030

Kriteria klasifikasi kesesuaian lahan dinilai berdasarkan perubahan kondisi aktual terhadap kondisi alaminya (Tabel 2). Perubahan ini tidak memperhatikan bagaimana kelas indeks konservasi pada kondisi alaminya, apakah baik atau buruk. Demikian pula, tidak memperhatikan kelas indeks konservasi pada kondisi aktual, apakah tetap buruk atau menjadi lebih baik. Hal ini yang menjadi kelemahan dalam menilai tingkat kesesuaian lahan berdasarkan perubahan kelas indeks konservasi aktual terhadap kelas indeks konservasi alami, tanpa memperhatikan kelas indeks konservasi alaminya. Kondisi alami pada tahun 2009, berdasarkan penilaian indeks konservasi menunjukkan bahwa kategori pere- sapan sangat rendah memiliki wilayah terluas sebesar $42 \%$ yang tersebar di seluruh kecamatan. Kategori wilayah dengan tingkat peresapan sangat tinggi justru memiliki luas terkecil, sebesar $1 \%$, yang berada di Kecamatan Jalancagak dan Sagalaherang (Gambar 2). Hal ini menggambarkan bahwa kondisi alami di DAS Ciasem hulu secara umum kurang baik.

Secara spasial, DAS Ciasem hulu terlihat memiliki kondisi aktual yang cukup baik karena distribusi lahan dengan kategori sesuai memiliki luas yang cukup besar. Namun, jika kita melihat pada kondisi alaminya, ternyata nilainya berkisar dari sangat rendah sampai sedang. Artinya, kondisi aktualnya pun memiliki kisaran nilai dari 
sangat rendah sampai sedang. Berdasarkan distribusi kesesuaian lahan, beberapa area di Kecamatan Cijambe, Cisalak, dan Tanjungsiang memiliki perbaikan penggunaan lahan dengan keberadaan penambahan luas kesesuaian lahan yang sesuai, artinya luas tersebut sejak tahun 2009 sampai dengan 2014 tidak berubah.

Berdasarkan distribusi kekritisan lahan (Gambar 3, 4, dan 5), terjadi peningkatan luas lahan dengan kategori sesuai. Hal tersebut menunjukkan bahwa sebenarnya pada periode tersebut pola penggunaan lahan tidak berubah. Beberapa daerah di Kecamatan Jalancagak dan Sagalaherang mengalami pengurangan lahan dengan kategori sangat kritis. Akan tetapi degradasi tetap lebih besar pada tahun 2014 karena peningkatan kesesuaian lahan kritis terjadi cukup tinggi. Hal ini menunjukkan kondisi aktual lebih buruk daripada kondisi alaminya.

Analisis perubahan pada tahun 2014 dan 2030 menunjukkan bahwa kesesuaian lahan dengan kategori sesuai hampir memenuhi luas DAS Ciasem hulu. Artinya, kondisi aktual sama dengan kondisi alaminya. Jadi, meskipun di Kecamatan Cisalak, Sagalaherang, dan Jalancagak pada tahun 2030 terjadi peningkatan luas wilayah sampai kategori sesuai, serta penurunan jumlah kategori lahan kritis dan sangat kritis, hal tersebut tidak menggambarkan bahwa skenario penggunaan lahan tahun 2030 cukup baik untuk dapat memperbaiki kondisi alaminya. Skenario penataan penggunaan lahan tahun 2030 masih perlu dikaji lebih lanjut agar mampu meningkatkan luas wilayah dengan tingkat peresapan air lebih tinggi dan menurunkan luas area dengan tingkat peresapan rendah.

Pendekatan secara spasial merupakan analisis yang baik untuk mengetahui distribusi kesesuaian lahan di DAS Ciasem hulu. Dengan analisis spasial lokasi-lokasi yang perlu mendapat perhatian dapat diketahui. Kecamatan Jalancagak dan Sagalaherang merupakan daerah yang perlu mendapat perhatian khusus karena kedua kecamatan ini telah mengalami peningkatan luas lahan kritis yang cukup tinggi sejak tahun 2014.

Kesesuaian lahan di suatu wilayah dapat dinilai berdasarkan indeks konservasi yang memperhitungkan kondisi alami dan kondisi aktualnya. Akan tetapi, penilaian ini memiliki kelemahan jika tingkat kesesuaian lahan hanya dinilai berdasarkan perubahan kelas indeks konservasi aktual terhadap kelas indeks konservasi alami saja. Kondisi alami merupakan hal penting dalam penilaian kesesuaian lahan karena merupakan acuan dalam penilaiannya. Penilaian dengan kategori sesuai bermakna bahwa kondisi aktual sama dengan kondisi alaminya. Kesalahan persepsi dapat terjadi terhadap kategori sesuai. Jika kesesuaian lahannya adalah kategori sesuai, namun diketahui kondisi alaminya kurang baik, maka pada kenyataannya kondisi aktualnya pun tetap kurang baik.

\section{Kesimpulan}

DAS Ciasem hulu memiliki kondisi kesesuaian lahan sesuai, kritis, dan sangat kritis. Dari tahun 2009 sampai dengan 2014 secara signifikan terjadi peningkatan wilayah dengan kategori kritis dan sangat kritis di semua wilayah. Skenario penataan penggunaan lahan tahun 2030 masih perlu dikaji lebih lanjut agar mampu meningkatkan kualitas dan kemampuan daya resap lahan terhadap air yang kondisinya telah terdegradasi sejak tahun 2009. Pendekatan secara spasial merupakan analisis yang baik untuk mengetahui distribusi kesesuaian lahan di DAS Ciasem hulu. Kesesuaian lahan di suatu wilayah dapat dinilai berdasarkan indeks konservasi yang memperhitungkan kondisi alami dan kondisi aktualnya. Akan tetapi, penilaian ini memiliki kelemahan jika tingkat kesesuaian lahan hanya dinilai berdasarkan perubahan kelas indeks konservasi aktual terhadap kelas indeks konservasi alami saja. Nilai kondisi alami merupakan hal penting dalam penilaian kesesuaian lahan. Meskipun kategori kesesuaian lahan merupakan kategori sesuai, akan tetapi jika diketahui kondisi alaminya kurang baik maka kondisi aktualnya tetap memiliki kondisi kurang baik.

\section{Ucapan Terima Kasih}

Penulis mengucapkan terima kasih kepada Dinas Pengelolaan Sumber Daya Air Provinsi Jawa Barat yang telah memberikan dukungan data untuk penelitian ini, kepada Kepala Pusat dan Koordinator kegiatan Prioritas Nasional (PN) 9 Pusat Penelitian Geoteknologi LIPI yang telah memberikan dukungan anggaran untuk melaksanakan kegiatan penelitian ini. 


\section{Referensi}

As-Syakur AR, Suarna IW, Adnyana IWS, Rusna IW. 2010. Studi Perubahan Penggunaan Lahan di DAS Badung. Jurnal Bumi Lestari 10(2):200-207.

Bappeda Kabupaten Subang. 2009. Penyusunan Rencana Tata Ruang Wilayah Kabupaten Subang. Laporan Analisis pekerjaan RTRW Kabupaten Subang. Bappeda Kabupaten Subang. 114 pp.

Collins MG, Steiner FR, Rushman MJ. 2001. Land-use Suitability Analysis in the United States: Historical Development and Promising Technological Achievements. Environ. Manag. 28 (5), 611-621 pp.

Dinas Sumber Daya Air. 2017. Buku Sumber Daya Air Provinsi Jawa Barat. Balai Pusat Data dan Informasi Sumber Daya Air. Dinas Sumber Daya Air. Pemerintah Daerah Provinsi Jawa Barat

Fakhrudin M, Daruati D. 2017. Zonasi Resapan Air Hujan Sebagai Dasar Konservasi Sumber Daya Air Das Cimanuk. LIMNOTEK Perairan Darat Tropis di Indonesia Vol. 24, No. 1, Juni $2017: 26-35$

Feizizadeh B, Blaschke T. 2013. Land Suitability Analysis for Tabriz County, Iran: a Multicriteria Evaluation Approach Using GIS. $J$. Environ. Plan. Manag. 56 (1), 1-23 pp.

Hardjowigeno, Sarwono. 1995. Ilmu Tanah. Akapres, Jakarta. 97 pp.

Kodoatie, Robert J. 2010. Tata Ruang Air. Bandung: Penerbit Andi, 66 pp.

Maria R, Lestiana H, 2014. Pengaruh Penggunaan Lahan Terhadap Fungsi Konservasi air tanah di Sub DAS Cikapundung. Jurnal RISET Geologi dan Pertambangan, Vol.24, No.2, Desember 2014, 77-89 pp.
Marull J, Pino J, Mallarach JM, Cordobilla MJ. 2007. A Land Suitability Index for Strategic Environmental Assessment in Metropolitan Areas. Landsc. Urban Plan. 81, 200-212 pp.

Mulyono A, Mulyadi D, Maria R. 2011. Deskripsi dan Klasifikasi Jenis Tanah di Wilayah Sagalaherang, Subang. Prosiding pemaparan hasil penelitian puslit geoteknologi LIPI 2011, tanggal 6 Desember 2011 ISBN 978-9798636-18-9. 37-43 pp.

Rismana GA, Firmansyah. 2011. Evaluasi pemanfaatan Ruang berdasarkan Indeks Konservasi di Sub DAS Cikapundung Hulu Provinsi Jawa Barat. Jurnal Lingkungan dan Bencana Geologi, Vol. 2 No. 1 April 2011: 49 $-66 \mathrm{pp}$.

Rojas C, Pino J, Jaque E. 2013. Strategic Environmental Assessment in Latin America: A Methodological Proposal for Urban Planning in the Metropolitan Area of Concepcion (Chile). Land Use Policy 30 (1), 519-527 pp.

Sabar. 1999. Indeks Konservasi sebagai Instrumen Pengendalian Pemanfaatan Ruang di Kawasan Bopunjur dalam Rangka Rancangan Keppres. Makalah Bahan Diskusi di Bappenas., Bandung: ITB. Rismana dan Firmansyah, 2011

Silitonga PH. 1973. Peta Geologi Lembar Bandung, Jawa, Skala 1:100.000. Direktorat Geologi, Bandung.

Soil Survey Staff. 2010. Keys to Soil Taxonomy.U.S. Department of Agriculture, Natural Resources Conservation Services. Eleventh Edition. 2010, 331 pp.

Nuraeni R, Sitorus SRP, Panuju DR. 2017. Analisis Perubahan Penggunaan Lahan dan Arahan Penggunaan Lahan Wilayah di Kabupaten Bandung. Buletin Tanah dan Lahan, 1 (1) Januari 2017: 79-85 